\title{
Theoretical Approach to the Physics of Fuel Cells
}

\author{
K. A. I. L. Wijewardena Gamalath, B. M. P. Peiris \\ Department of Physics, University of Colombo, Colombo 03, Sri Lanka. \\ E-mail address: imalie@phys.cmb.ac.lk
}

\begin{abstract}
Ion transport rate of PAFC, AFC, PEMFC, DMFC and SOFC fuel cells under the influence of an electric field and concentration gradient were evaluated for static electrolytes. AFC are the best fuel cells for higher current applications while direct methanol fuel cells DMFC are the best for lower current applications at lower temperatures. An equation for voltage output of a general fuel cell was obtained in terms of temperature and partial pressure of reactants. Performance of a $2 \mathrm{D}$ fuel cell was analyzed by simulating polarization and power curves for a fuel cell operating at $60^{\circ} \mathrm{C}$ with a limiting current density of $1.5 \mathrm{~A} \cdot \mathrm{cm}^{-2}$. The maximum power for this fuel cell was $8.454 \mathrm{~W}$ delivering $82 \%$ of maximum loading current density. When the temperature was increased by one third of its original value, the maximum power increased by $6.75 \%$ and at $60{ }^{\circ} \mathrm{C}$ for a 10 times increment of partial pressure of reactants, the maximum power increased by $2.43 \%$.The simulated power curves of the fuel cells were best described by cubic fits.
\end{abstract}

\section{Keywords:}

Fuel cell; ion transport rate; concentration gradient; polarization losses; polarization curve; power curve

\section{INTRODUCTION}

A fuel cell, a device that generates electric energy by a chemical reaction is a clean alternative to the conventional fossil fuel based systems as water is the byproduct. Because of their low environmental impact, they are currently used in almost all applications of power especially those are energy limited. As many of the transport phenomena inside a fuel cell cannot be observed and measured directly, mathematical modeling is an effective tool in understanding these phenomena. The one dimensional models introduced by Verbrugge and Hill [1] and Bernadi and Verbrugge [2] laid a good foundation for polymer solar cells. Springer et al [3] presented empirical relation for the parameters such as diffusion coefficient, electro-osmotic drag coefficient, membrane conductivity and water absorption isotherms etceteras. Computational fluid dynamics into fuel cell modeling was introduced by Guraue et al [4] by developing a two dimensional polymer fuel cell model that included fluid flow, mass transfer and electro-kinetics.

The techniques of computational two dimensional fluid dynamics models assuming a single-phase gaseous flow isothermal was developed by Kazim et al [5] for the cathode and by Singh et al [6] for the whole cell. Three-dimensional models by Dutta et al [7] considered straight channel flow under isothermal conditions and flow in a serpentine channel. Only few models exist for liquid water. A model by You and Liu [8] focused on the mass transport limitations and water 
management in a two dimensional cathode under isothermal conditions. Most of the models are validated on a global scale with polarization curves, which are unable to capture the current density distributions on a local level. From a segmented cell, Lum [9] validated a model with both global polarization curves and local current density distributions.

In this study the ion transport rates (current) under the influence of electric field and the concentration gradient were calculated for fuel cells of phosphoric acid (PAFC), proton exchange membrane (PEMFC), solid oxide (SOFC), alkaline (AFC) and direct methanol (DMFC) under static electrolyte conditions. For a fuel cell operating at $80{ }^{\circ} \mathrm{C}$ temperature, the polarization losses namely activation overpotential, ohmic overpotential for a Nafion membrane and concentration overpotential were studied.

An equation for voltage output of a general fuel cell was obtained in terms of temperature and partial pressure of reactants. Using this equation, performance of a two dimensional fuel cell operating at $60{ }^{\circ} \mathrm{C}$ with a limiting current density $1.5 \mathrm{~A} \cdot \mathrm{cm}^{-2}$ was analyzed through simulating polarization and power curves. The best fits for these curves were obtained. Simulations were done for different temperature and partial pressure values.

\section{CURRENTS IN FUEL CELLS}

A fuel cell generates electric energy by a chemical reaction taking place at a negatively (anode) and a positively charged (cathode) electrodes with an electrolyte layer carrying electrically charged particles from one electrode to the other and a catalyst layer speeding up the reactions at the electrodes (Figure 1). A current created in a fuel cell due to ion transport through the electrolyte is given by the equation

$$
I=n z F
$$

where $n$ is the molar rate of transfer of ions through the electrolyte, $F$ is the Faraday's constant and $z$ is the charge number of the ion. The ion transfer through the electrolyte occurs by several mechanisms: (a) mass diffusion ${ }^{10}$ a random thermal motion on a microscopic scale resulting a net flux even though the motion of each individual molecule is completely random, (b) due to convection, a result of buoyancy forces resulting from a density gradient and $(c)$ due to migration of charged species driven by an electrical potential difference. Flux rate $n_{j}$ of the species $j$ is given by Nernst-Planck equation as

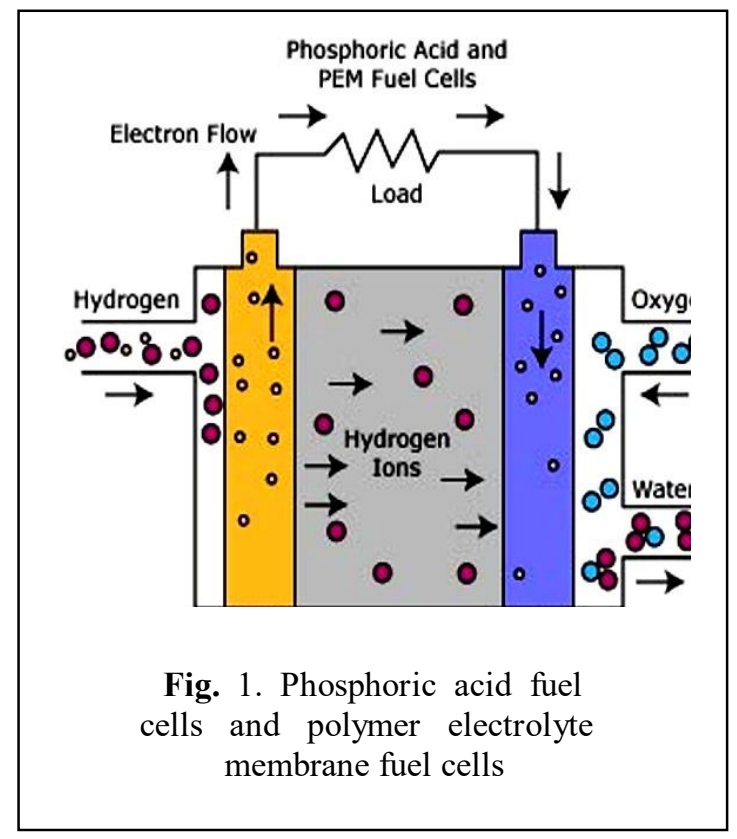




$$
n_{j}=-D \frac{d C_{j}}{d x}+C_{j} V-\frac{Z_{j} F}{R T} D_{j} C_{j} \frac{d \phi}{d x}
$$

where $D_{\mathrm{j}}$ is the mass diffusivity coefficient and $C_{j}$ is the concentration, $v$ is the solution velocity, $\phi$ is the potential, $\boldsymbol{T}$ is the temperature in Kelvin and $R$ is the universal gas constant. The above equation reduces to simple diffusion and convection in the absence of a potential gradient. In an electrolyte with no convection or concentration gradient, Nernst-Planck equation reduces to Ohm's law. An expression for current in an electrolyte can be obtain by using equation 1 and 2

$$
i=\left(-D \frac{d C_{j}}{d x}+C_{j} V-\frac{Z_{j} F}{R T} D_{j} C_{j} \frac{d \phi}{d x}\right) Z_{j} F
$$

This is a general expression for current appropriate for all electrolyte systems. In static electrolyte systems [12], only diffusion and migration terms remain and at open-circuit condition they balance each other such that no net current result.

There are several classes of fuel cells, identified by their electrolytes. These are presented in table 1. For both Phosphoric acid fuel cells (PAFC) and polymer electrolyte membrane fuel cells (PEMFC), the hydrogen molecules splitting at the anode into hydrogen ions are transport across the electrolyte to the cathode. Oxygen, usually in the form of air is supplied to the cathode and combines with the electrons and the hydrogen ions to produce water (Figure1).

For a polymer exchange membrane fuel cell (PEMFC) of static electrolyte with $25 \mathrm{~cm}^{2}$ active area, $50 \mu \mathrm{m}$ thickness and $0,9 \cdot 10^{-6} \mathrm{~cm}^{2} \cdot \mathrm{s}^{-1}$ diffusion coefficient of $\mathrm{H}^{+}$ions [9], current densities obtained for applied potential difference between $0.6-1.0 \mathrm{~V}$ at $80{ }^{\circ} \mathrm{C}$ are shown in Figure 2.

The current densities for a phosphoric acid fuel cell (PAFC) under static electrolyte condition having $0,3 \cdot 10^{-5} \mathrm{~cm}^{2} \cdot \mathrm{s}^{-1}$ diffusion coefficient with same active area and thickness operating at $170{ }^{\circ} \mathrm{C}$ temperature are shown in figure 3. Although PEMFC have lower currents than PAFC because of their lower operating temperature allowing rapid start up they are used in automotive power applications.

Another advantage of PEMFC is that its electrolyte is a solid material and is less expensive to manufacture than the liquid electrolyte used in PAFC.

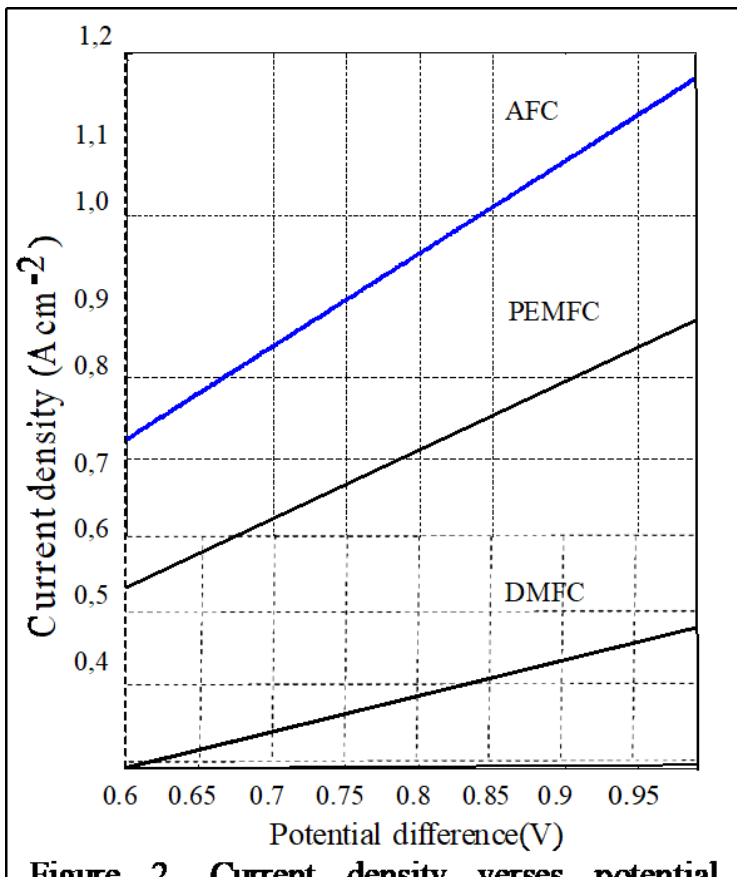

Figure 2. Current density verses potential difference for PEMFC, AFC and DMFC at $80^{\circ} \mathrm{C}$ 
Table 1. Fuel Cell Types

\begin{tabular}{|c|c|c|c|}
\hline Fuel Cell & $\begin{array}{l}\text { Electrolyte } \\
\text { Used }\end{array}$ & $\begin{array}{c}\text { Operating } \\
\text { Temperature }\end{array}$ & Electrode reactions \\
\hline $\begin{array}{l}\text { Phosphoric acid } \\
\text { (PAFC) }\end{array}$ & $\begin{array}{l}\text { Phosphoric } \\
\text { acid }\end{array}$ & $150-200{ }^{\circ} \mathrm{C}$ & Anode reaction: $2 \mathrm{H}_{2} \rightarrow 4 \mathrm{H}^{+}+4 \mathrm{e}^{-}$ \\
\hline $\begin{array}{l}\text { Polymer exchange } \\
\text { membrane (PEMFC) }\end{array}$ & $\begin{array}{l}\text { Polymer } \\
\text { Membrane }\end{array}$ & $\begin{array}{l}70-100{ }^{\circ} \mathrm{C} \\
\text { typically } 80{ }^{\circ} \mathrm{C}\end{array}$ & Cathode reaction: $\mathrm{O}_{2}+4 \mathrm{H}^{+}+4 \mathrm{e}^{-} \rightarrow 2 \mathrm{H}_{2} \mathrm{O}$ \\
\hline \multirow[t]{2}{*}{ Alkaline (AFC) } & Potassium & & Anode reaction: $2 \mathrm{H}_{2}+4 \mathrm{OH}^{-} \rightarrow 4 \mathrm{H}_{2} \mathrm{O}+4 \mathrm{e}^{-}$ \\
\hline & & $65-100{ }^{\circ} \mathrm{C}$ & Cathode reaction: $\mathrm{O}_{2}+2 \mathrm{H}_{2} \mathrm{O}+4 \mathrm{e}^{-} \rightarrow 4 \mathrm{OH}^{-}$ \\
\hline \multirow{3}{*}{$\begin{array}{l}\text { Direct methanol } \\
(\mathrm{DMFC})\end{array}$} & & & Anode reaction: \\
\hline & $\begin{array}{l}\text { Polymer } \\
\text { Membrane }\end{array}$ & $30-80{ }^{\circ} \mathrm{C}$ & $\mathrm{CH}_{3} \mathrm{OH}+\mathrm{H}_{2} \mathrm{O} \rightarrow \mathrm{CO}_{2}+6 \mathrm{H}^{+}+6 \mathrm{e}^{-}$ \\
\hline & & & Cathode reaction: $\frac{3}{2} \mathrm{O}_{2}+6 \mathrm{H}^{+}+6 \mathrm{e}^{-} \rightarrow 3 \mathrm{H}_{2} \mathrm{O}$ \\
\hline \multirow[t]{2}{*}{ Solid oxide (SOFC) } & Yittria & & Anode reaction: $2 \mathrm{H}_{2}+2 \mathrm{O}^{2-} \rightarrow 2 \mathrm{H}_{2} \mathrm{O}+4 \mathrm{e}^{-}$ \\
\hline & Zirconia & $600-1000{ }^{\circ} \mathrm{C}$ & Cathode reaction: $\mathrm{O}_{2}+4 \mathrm{e}^{-} \rightarrow 2 \mathrm{O}^{2-}$ \\
\hline
\end{tabular}

Alkaline fuel cells use a solution of potassium hydroxide in water as the electrolyte and a variety of non precious metals as a catalyst at the anode and cathode. The concentration of potassium hydroxide can be varied with the fuel cell operating temperature.

The charge carriers for an AFC are the hydroxyl ions $\left(\mathrm{OH}^{-}\right)$that migrates from the cathode to the anode where they react with hydrogen to produce water and electrons. Water formed at the anode migrates back to the cathode to regenerate hydroxyl ions (Table 1). The current densities for an alkaline fuel cell of same active area and electrolyte thickness operating at $80{ }^{\circ} \mathrm{C}$ temperature with a diffusion coefficient of $0,12 \cdot 10^{-5} \mathrm{~cm}^{2} \cdot \mathrm{s}^{-1}$ are shown in figure 2 .

In direct methanol fuel cells (DMFC), the electrolyte is a polymer and the charge carriers are the hydrogen ions. However, the liquid methanol $\left(\mathrm{CH}_{3} \mathrm{OH}\right)$ is oxidized in the presence of water at the anode generating $\mathrm{CO}_{2}$, hydrogen ions and electrons. The hydrogen ions travelling through the electrolyte react with oxygen from air and together with electrons travelling through the external circuit, form water at the anode completing the circuit (Table 1).

The current densities for the direct methanol fuel cell of same active area and electrolyte thickness operating at $80{ }^{\circ} \mathrm{C}$ temperature are shown in figure 2 . These are lower than the other fuel cell types. 


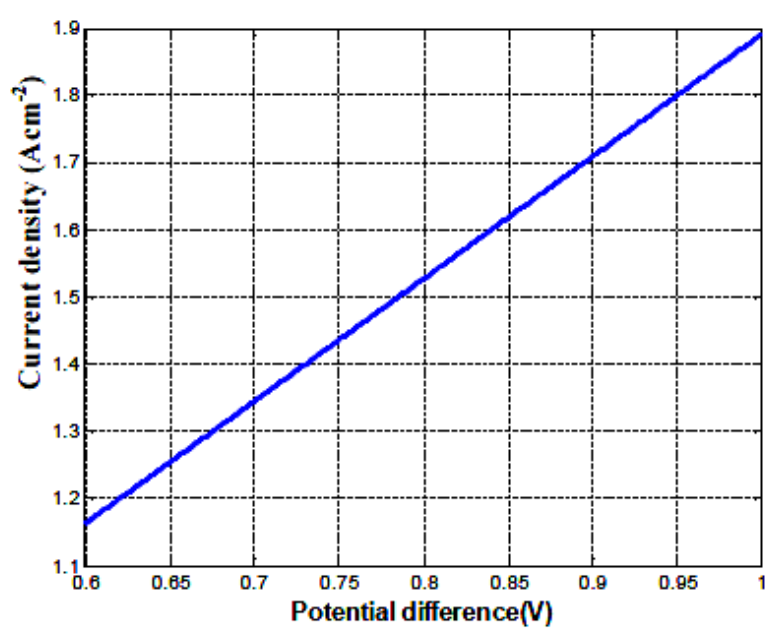

Figure 3: Current density verses potential difference for $\mathrm{PAFC}$ at $170^{\circ} \mathrm{C}$

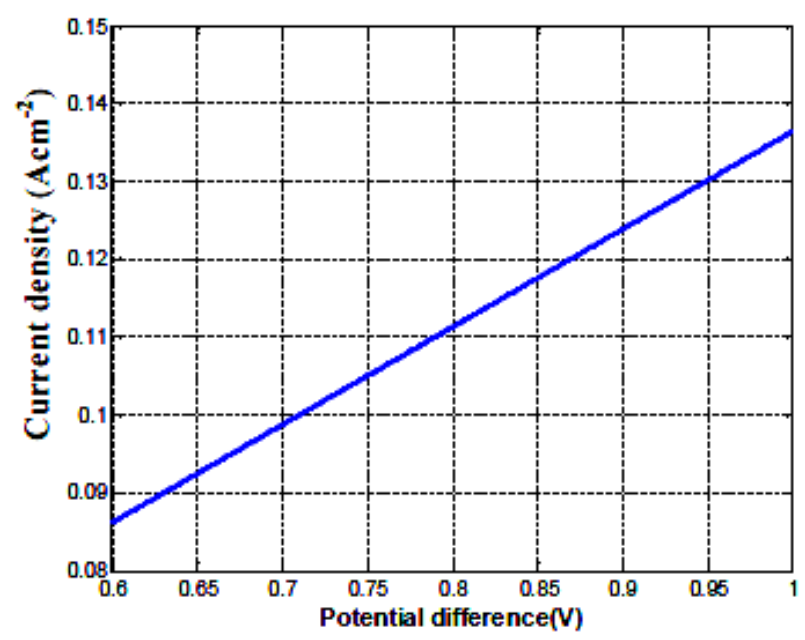

Figure 4: Current density verses potential difference for $\mathrm{SOFC}$ at $700^{\circ} \mathrm{C}$

The solid oxide fuel cell (SOFC) is the highest temperature fuel cell that can operate over a wide temperature range between $600{ }^{\circ} \mathrm{C}$ to $1000{ }^{\circ} \mathrm{C}$. The electrolyte uses in SOFC is a thin solid ceramic material (solid oxide). The charge carriers, oxygen ions conducted through the electrolyte combine with hydrogen at the anode releasing four electrons. The electrons travel through an external circuit providing electric power and producing by product water.

The current densities for SOFC of same active area and electrolyte thickness with operating at $700{ }^{\circ} \mathrm{C}$ temperature with a diffusion coefficient of $0,1 \cdot 10^{-6} \mathrm{~cm}^{2} \cdot \mathrm{s}^{-1}$ are shown in figure 4. The current is less compared to other fuel cells due to smaller diffusion coefficient of oxygen ions and larger molar volume caused by higher temperature. The current density can be increased bydecreasing the thickness of the membrane.

\section{CELL POTENTIAL}

The electrochemical energy conversion, the conversion of the free energy associated with a chemical reaction directly into electrical energy is a measure of the maximum electrical work $W_{\text {ele }}$ that a system can perform at a constant temperature and pressure. This is given by the negative change in Gibbs free energy ${ }^{11} \Delta G$. This relation is valid at any constant temperature and pressure for most fuel cell systems. The standard reversible cell potential can be written as

$$
W_{e l e}=-\Delta G=-n F E_{r} \Rightarrow E_{r}=-\frac{\Delta G}{n F}=-\frac{\Delta H-T \Delta S}{n F}
$$

where $H$ is the enthalpy, $T$ is the absolute temperature, $S$ is the entropy, $n$ is the number of moles of electrons transferred per mol of fuel consumed, $F$ is the Faraday's constant $(96,485$ coulombs 
per mole of electrons) and $E_{r}$ is the standard reversible voltage. Since the change in entropy is negative, the open circuit output voltage decreases with increasing temperature. For a chemical reaction $a A+b B \rightarrow c C+d D$ the change in Gibbs free energy between the products and reactants can be written as

$$
\Delta G=c G_{c}+d G_{d}-a G_{a}-b G_{b}
$$

Often it is advantageous to operate a fuel cell above atmospheric pressures. The typical pressure range used for fuel cells is atmospheric pressure to 6 or 7 bars. For the reaction considered, the change in Gibbs free energy with pressure can be obtain by Nernst equation

$$
G=G_{0}+R T \ln \left(\left(\frac{P_{C}}{P_{0}}\right)^{c}\left(\frac{P_{D}}{P_{0}}\right)^{d} /\left(\frac{P_{A}}{P_{0}}\right)^{a}\left(\frac{P_{B}}{P_{0}}\right)^{b}\right)
$$

where $P$ is the partial pressure of the reactant or product species, and $P_{0}$ is the reference pressure. For the hydrogen-oxygen fuel cell reaction, the Nernst equation read

$$
G=G_{0}+R T \ln \left(P_{H_{2}} \times P_{O_{2}}^{0.5} / P_{H_{2} O}\right)
$$

Then the cell potential as a function of temperature and partial pressure of reactants is

$$
E_{r}(T, P)=\left(\frac{\Delta H-T \Delta S}{n F}\right)+R T \ln \left(\frac{P_{H_{2}} \times P_{O_{2}}^{0.5}}{P_{H_{2} O}}\right)
$$

The maximum electrical energy output, and the potential difference between the cathode and anode is achieved when the fuel cell is operating under the thermodynamically reversible condition. Therefore the maximum possible cell potential is the reversible cell potential.

\section{POLERIZATION LOSSES}

In practice the open circuit potential is significantly lower than the theoretical potential due to losses in the fuel cell even when no external current is generated. There are three main losses, activation polarization $V_{a c t}$, ohmic polarization $V_{\text {ohmic }}$ and concentration polarization $V_{\text {conc }}$. The irreversible voltage loss $V_{\text {irrev }}$ occurring at the fuel cell is

$$
V_{\text {irrev }}=\left(V_{\text {act }}+V_{\text {ohmic }}+V_{\text {conc }}\right)
$$

The voltage overpotential required to overcome the energy barrier for the electrochemical reaction, called activation polarization [10] measures the catalyst effectiveness at a given temperature. This can be derived from the Butler-Volmer equation as

$$
i=I_{C}+I_{A}=i_{0}\left[-\exp \left(-\frac{\alpha_{C} n F \eta}{R T}\right)+\exp \left(\frac{\alpha_{A} n F \eta}{R T}\right)\right]
$$


where $I_{c}$ and $I_{A}$ are cathodic and anodic current densities respectively and $i_{o}$ is the reaction exchange current density. $\alpha_{c}$ and $\alpha_{A}$ are the charge transfer coefficients at the cathode and anode

describing the amount of electrical energy applied in changing the rate of the electro chemical reaction, $n$ is the number of exchange protons per mole of reactant and $\eta$ is the activation overpotential term. Assuming that $\eta$ has a higher negative value, i.e. $I_{c}>>I_{A}$, an expression for the activation overpotential can be obtained as

$$
\Delta V_{a c t}=\eta=-\frac{R T}{n \propto_{C} F} \ln \left(\frac{i}{i_{0}}\right)
$$

For a fuel cell operating at $80^{\circ} \mathrm{C}$ temperature with a transfer coefficient of 0.5 activation losses for different exchange currents are shown in figure 5. For the same fuel cell with an exchange current density of $10^{-3}$ $\mathrm{A} \cdot \mathrm{cm}^{-2}$, activation losses for different transfer coefficients are shown in Figure 6 . The variation in the activation overpotential for small current densities is large indicating that the activation overpotential dominates at low current density values.

For large exchange current densities the system has insignificant activation overpotential. The exchange current can be viewed as an "idle" current for charge exchange across the interface. If only a small net current is drawn from the fuel cell, only a tiny overpotential will be required to obtain it. If a net current is required that exceeds the exchange current, the system has to be driven to deliver the charge at the required rate, and this can only be achieved by applying a significant overpotential. This is a measure of the system's ability to deliver a net current with significant energy loss. When the transfer coefficient is low, the activation overpotential is large for any particular net current (figure 6). If the transfer coefficient is large, the system will supply large currents with small activation overpotential.

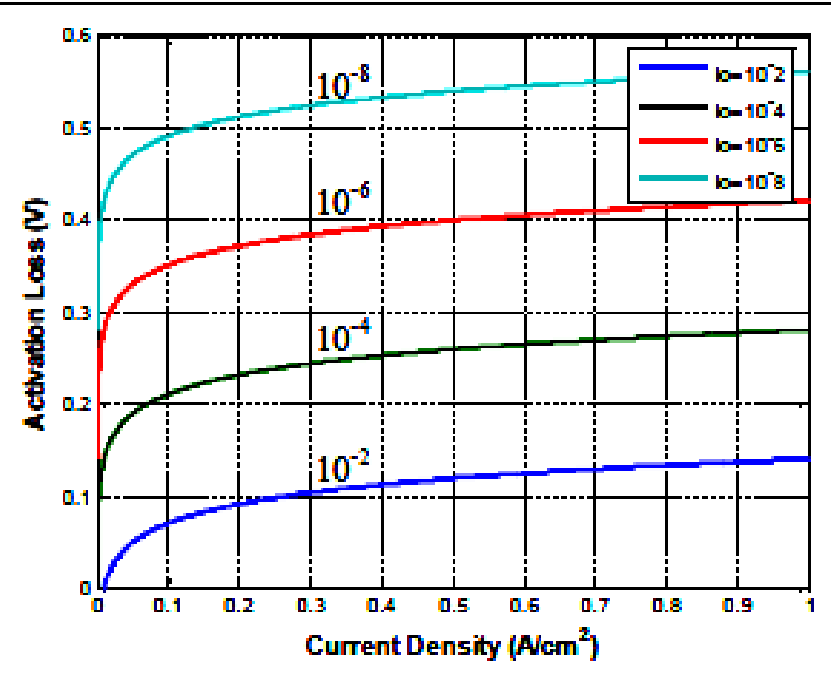

Figure 5: Activation loss as a function of current density

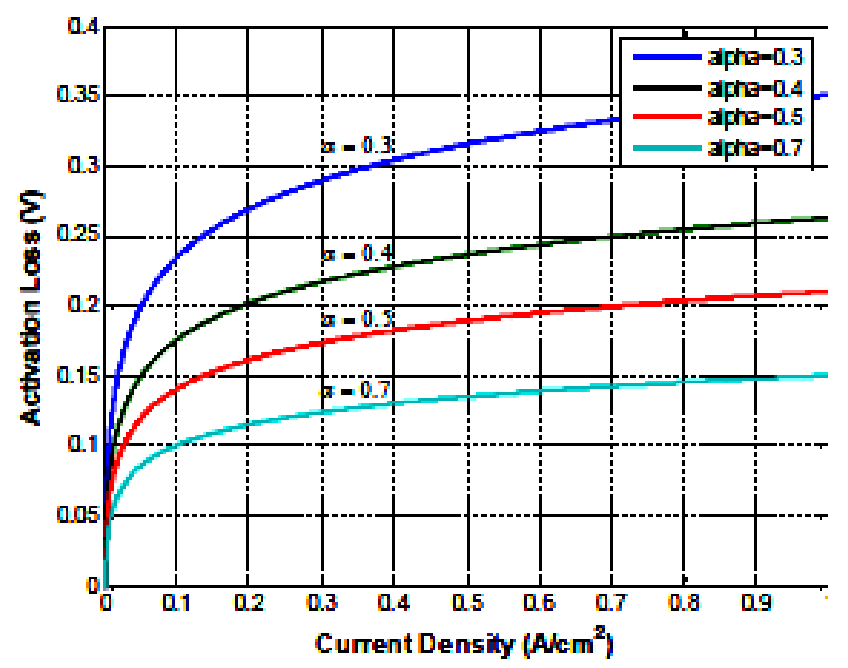

Figure 6: Activation loss as a function of transfer coefficient 
Every material has an intrinsic resistance to charge flow causing an ohmic polarization, which results in a loss in cell voltage called Ohmic loss. This loss due to the electronic $\left(R_{\text {elec }}\right)$ and ionic $\left(R_{\text {ionic }}\right)$ fuel cell resistances can be written as

$$
v_{\text {ohmic }}=i R_{\text {ohmic }}=i\left(R_{\text {elec }}+R_{\text {ionic }}\right)
$$

Ionic resistance represents the ionic resistance of the electrolyte while electronic resistance includes the total electrical resistance of all other conductive components, including the bipolar plates, cell interconnects and contacts. The largest ohmic loss occurs during the transport of ions through the membrane. This resistance strongly depending on the membrane water content is described by the parameter $\lambda$

$$
\lambda=0.043+17.81 \phi_{m}-39.85 \phi_{m}^{2}+36 \phi_{m}^{3}
$$

where $\phi_{m}$ is the membrane relative humidity. Water uptake results in membrane swelling, which changes the membrane thickness along with its conductivity [3].

Therefore the resistance of the membrane changes with water saturation and thickness. Therefore the ionic resistance ${ }^{9}$ is given by

$R_{\text {ionic }}=\int_{0}^{t_{m}} \frac{d z}{(0.005139 \lambda(z)-0.00326) e^{1268(1 / 303-1 / T)}}$

parameter $t_{m}$ is the membrane thickness and $T$ is temperature of the membrane. The denominator gives the ionic conductivity $\sigma$ correlated to water content and temperature.

Fuel cell's electrode electronic resistance can be written as,

$$
R_{\text {elec }}=\frac{2 \times l_{d}}{\sigma_{d}}
$$

where $l_{d}$ is the diffusion layer thickness and $\sigma_{d}$ is the diffusion layer electronic conductivity.

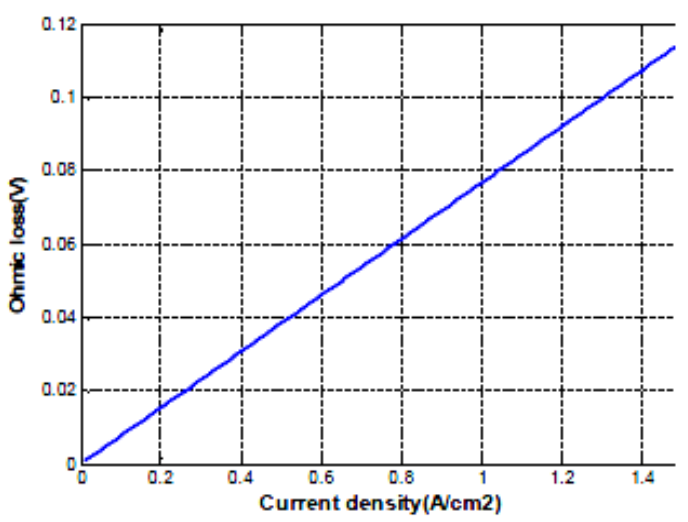

Figure 7: Ohmic loss and current density

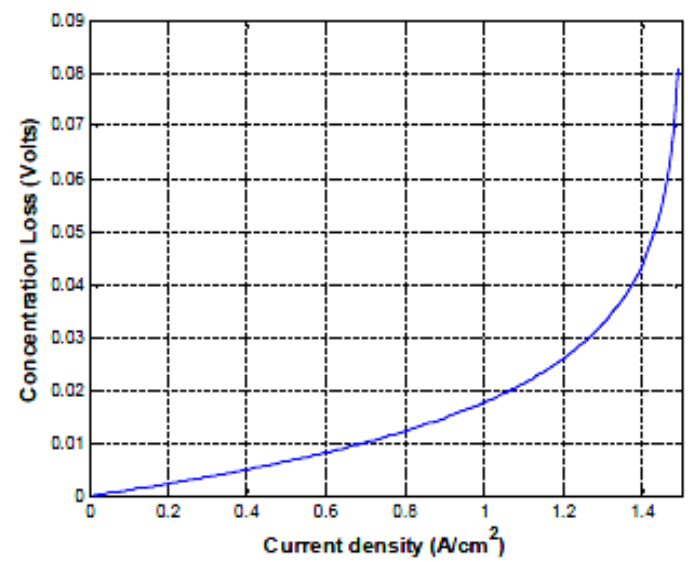

Figure 8: Concentration loss verses current density

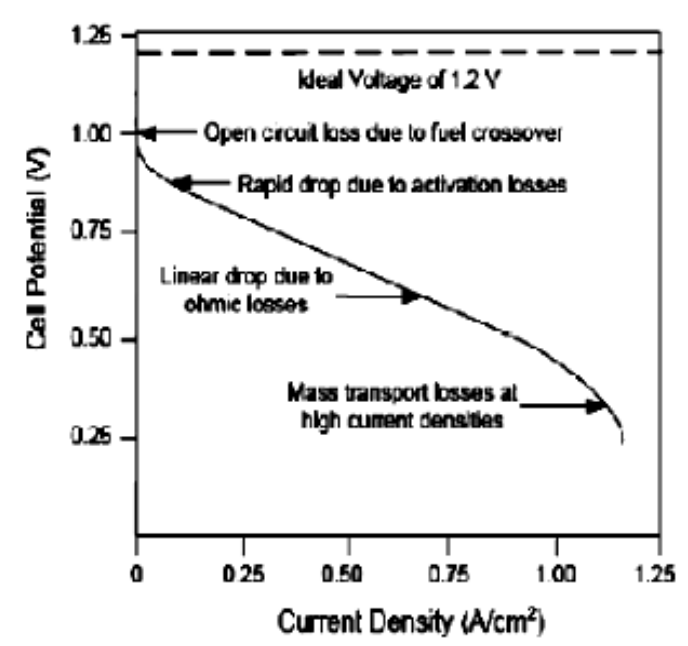

Figure 9: Typical polarization curve for the fuel cell 
For a polymer exchange fuel cell with a Nafion membrane of $50 \mu \mathrm{m}$ thickness operating at $80{ }^{\circ} \mathrm{C}$, the water content across the membrane was assumed as $\lambda(\mathrm{z})=5+2 \mathrm{e}^{100 \mathrm{z}}$. The conductivity $\sigma(\mathrm{z})=0.0411+0.00188 \mathrm{e}^{100 \mathrm{z}}$ lead to a resistance of $0.0766295 \Omega \cdot \mathrm{cm}^{-2}$. This value depends on the temperature. With the increase in temperature conductivity increases and the resistance per unit area in the membrane reduces. For the same fuel cell, ohmic losses for current densities are shown in figure 7 . The ohmic loss increases with current density linearly.

Concentration polarization occurs due to a decrease in the concentration of the reactants at the electrode-electrolyte interface. A steady supply of the reactants is required at the electrodeelectrolyte interface to maintain the flow of electric current. Due to diffusion or convection problems in the electrolyte, the concentration of the reactants is not maintained at the initial level. Reaction product accumulation can also cause dilution of reactants. The concentration gradient thus formed, causes a drop in electrode activity and the terminal voltage is reduced. The concentration overpotential is

$$
V_{\text {concen }}=-\frac{R T}{n F} \ln \left(1-\frac{i}{i_{L}}\right)
$$

where $i_{L}$ represents the limiting current density which describes the maximum current density that can flow out from the electrode of a fuel cell.

A fuel cell operating at temperature $60{ }^{\circ} \mathrm{C}$ was considered with the assumption that limiting current density $\left(i_{L}\right)$ was $1.5 \mathrm{Acm}^{-2}$.

The concentration polarization in terms of current density is shown in figure 8 . Concentration polarization dominates at higher current density values.

A polarization curve due to all three losses is shown in figure 9 .

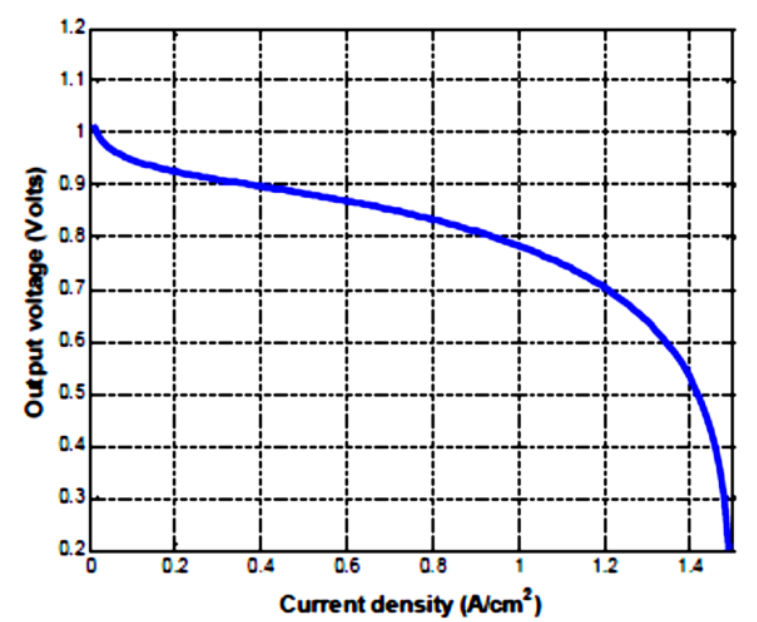

Figure 10: Simulated data for the polarization curve at $60^{\circ} \mathrm{C}$

\section{SIMULATING POLARIZATION AND POWER CURRES}

An expression for output voltage in terms of temperature and partial pressure was obtain as

$$
\begin{gathered}
V=V_{\text {rev }}-V_{\text {irrev }} \\
V(i)=-\left(\frac{\Delta G}{n F}\right)+R T \ln \left(\frac{P_{\mathrm{H}_{2}} \times P_{\mathrm{O}_{2}}^{0.5}}{P_{\mathrm{H}_{2} \mathrm{O}}}\right)-\frac{R T}{n \propto F} \ln \left(\frac{i}{i_{0}}\right)-\frac{R T}{n F} \ln \left(1-\frac{i}{i_{L}}\right)-i\left(R_{\text {ele }}+R_{\text {ionic }}\right)
\end{gathered}
$$


where $V_{\text {rev }}$ is the reversible (maximum) voltage of the fuel cell. A fuel cell with an active area of 10 $\mathrm{cm}^{2}$ at a temperature of $600{ }^{\circ} \mathrm{C}$ with $\alpha=0,5, i_{\mathrm{L}}=1,5 \mathrm{~A} \cdot \mathrm{cm}^{-2}$ and $\mathrm{i}_{\mathrm{o}}=10^{-6} \mathrm{~A} \cdot \mathrm{cm}^{-2}$ was considered.

The membrane humidity was taken as $100 \%$ and the partial pressures of hydrogen, oxygen and water as $0.99510^{5} \mathrm{~Pa}, 0.60610^{5} \mathrm{~Pa}$ and $0.38910^{5} \mathrm{~Pa}$ respectively. Using these values, a polarization curve was simulated (figure 10). Since the figure indicates the existence of a non linear relationship between the current density and the output voltage, a cubic polynomial was fitted to the data (Figure 11). In order to check the validity of the fitted model normal probability plot was used. The relationship between the current density and the output voltage described by this cubic fit model is given by

$$
V(i)=1.005-0.5847 \times i+0.895 \times i^{2}-0.519 \times i^{3}
$$

For the same fuel cell, using equation 18, a power curve was simulated. This is shown in figure 12 . When current density of the fuel cell increases, power delivered from the fuel cell increases reaching a maximum value before decreasing. A cubic polynomial was fitted to the data set (Figure 12) and the validity of the fitted model was checked by a normal probability plot. The relationship between the current density and the power of a fuel cell described by the cubic fit model is given by

$$
\begin{gathered}
P(i)=0.524+3.937 \cdot i+ \\
10.931 \cdot i^{2}-7.406 \cdot i^{3}
\end{gathered}
$$

The maximum power for this fuel cell was $8.45 \mathrm{~W}$ delivered at a current density of $1.23 \mathrm{Acm}^{-2}$. This represents $82 \%$ of the maximum loading.

The corresponding output voltage for the maximum power was $0.693 \mathrm{~V}$. In this loading value, fuel cell losses are around $45 \%$. Therefore, only $55 \%$ of the theoretical power will be available. The maximum power obtained from fitting a cubic model was $8.246 \mathrm{~W}$.

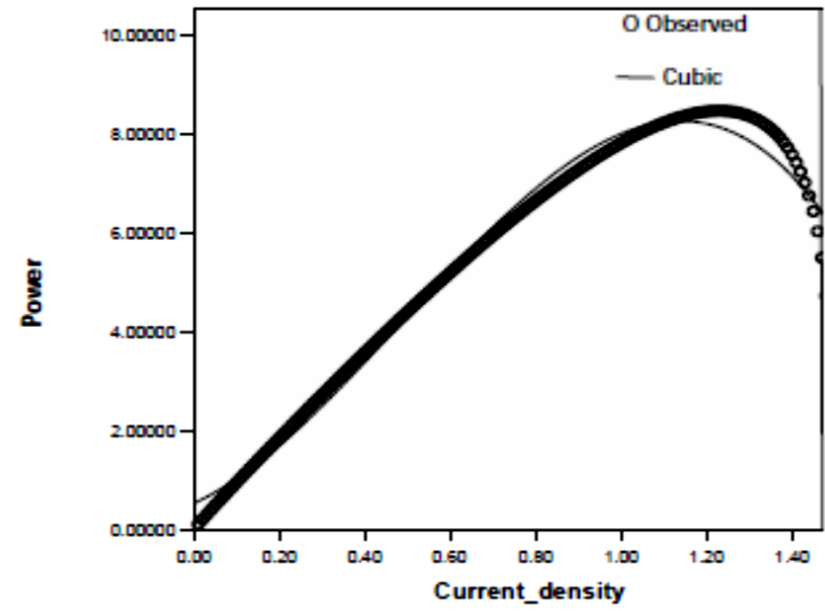

Figure 12: Fitted cubic curve and actual data for the power curve at $60^{\circ} \mathrm{C}$

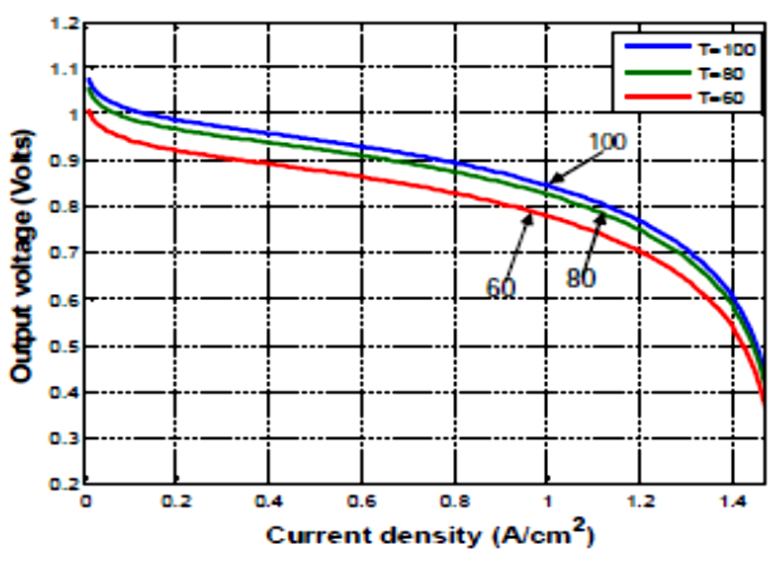

Figure 13: Polarization curves for $60^{\circ} \mathrm{C}, 80^{\circ} \mathrm{C}$ and $100^{\circ} \mathrm{C}$ 
While keeping all the other parameters constant, operating temperature of the fuel cell was changed and the effects on the polarization curve and power curve are shown in figure 13 and 14 respectively. These plots show that increase in fuel cell's operating temperature cause increase in fuel cell's output voltage and power output. Table 2 gives the maximum power and maximum power current density variations with temperature. Although the maximum power increases with temperature, they occur almost around the same current density value of $1.2 \mathrm{~A} \cdot \mathrm{cm}^{-2}$.

Table 2. Maximum power and maximum power current densities for different temperature values.

\begin{tabular}{|c|c|c|}
\hline Temperature $\left({ }^{\circ} \mathbf{C}\right)$ & Maximum power (W) & $\begin{array}{c}\text { Maximum power } \\
\text { current density } \mathbf{( A \cdot \mathbf { c m } ^ { - 2 }}\end{array}$ \\
\hline 60 & 8.45 & 1.23 \\
\hline 80 & 9.02 & 1.24 \\
\hline 100 & 9.27 & 1.25 \\
\hline
\end{tabular}

While keeping the fuel cell temperature at $60{ }^{\circ} \mathrm{C}$ and other parameters constant, partial pressures of $\mathrm{H}_{2}, \mathrm{O}_{2}$ and $\mathrm{H}_{2} \mathrm{O}$ taken to be equal were varied as $10^{5}, 10^{6}$ and $10^{7} \mathrm{~Pa}$. The resulting power curves are shown in Figure 15. Table 3 presents the maximum power and maximum power current densities for different pressure values. As partial pressures of reactants were increased maximum power also increased although the variation is less than the effect due to temperature.

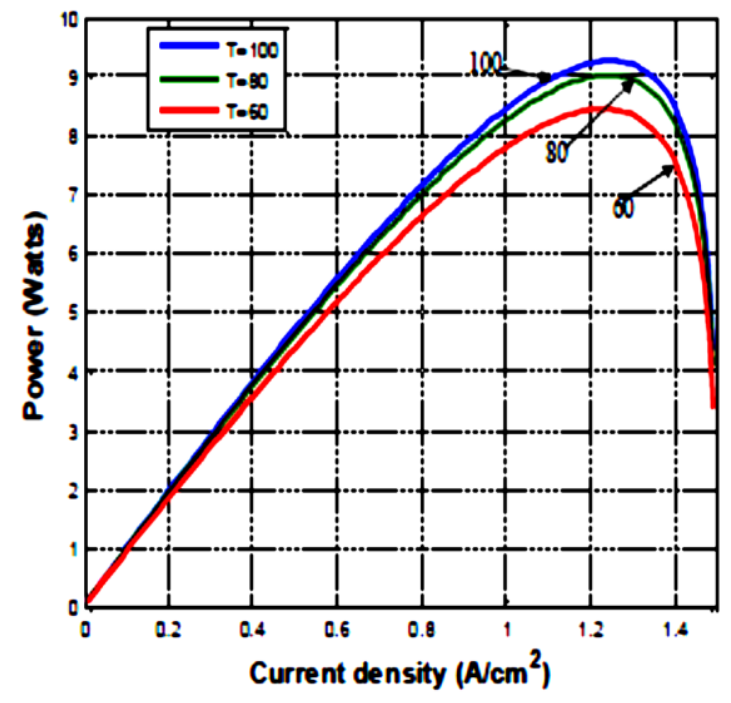

Figure 14: Power curves for $60^{\circ} \mathrm{C}, 80^{\circ} \mathrm{C}$ and $100^{\circ} \mathrm{C}$

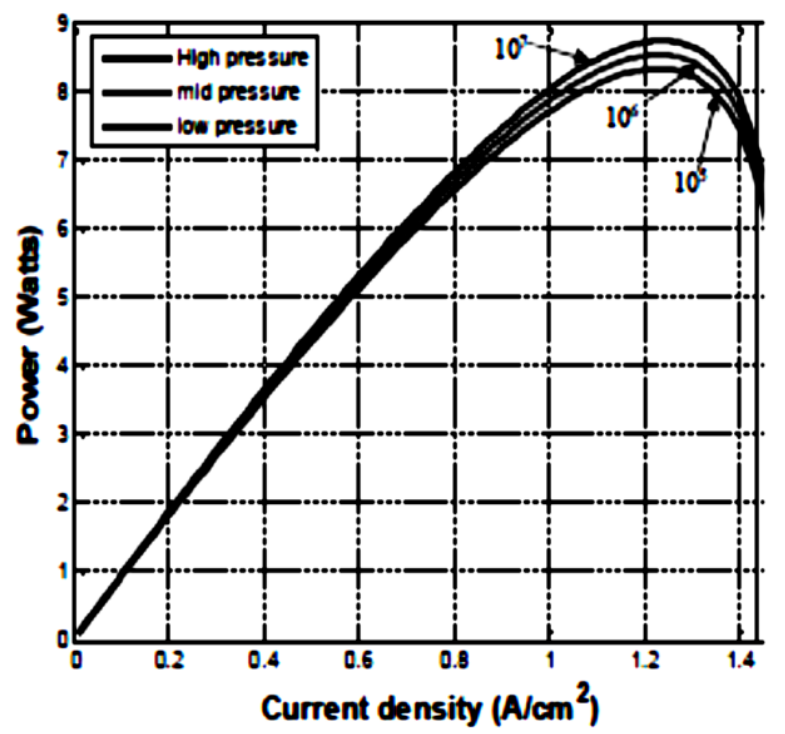

Figure 15: Power curve for $10^{5} \mathrm{~Pa}, 10^{6} \mathrm{~Pa}$ and $10^{7} \mathrm{~Pa}$ pressures at $60^{\circ} \mathrm{C}$ 
Table 3. Maximum power and maximum power current densities for different pressure values.

\begin{tabular}{|lcc|}
\hline \multicolumn{1}{|c}{ Pressure (Pa) } & $\begin{array}{c}\text { Maximum } \\
\text { power }(\mathbf{W})\end{array}$ & $\begin{array}{c}\text { Maximum power } \\
\text { current density }\left(\mathbf{A} / \mathbf{c m}^{2}\right)\end{array}$ \\
Low pressure $10^{5}$ & 8.33 & 1.23 \\
Middle pressure $10^{6}$ & 8.54 & 1.23 \\
High pressure $10^{7}$ & 8.74 & 1.24
\end{tabular}

\section{CONCLUSION}

Under static electrolyte conditions, alkaline fuel cells (AFC) are the best fuel cells for higher current applications while direct methanol fuel cells (DMFC) are the best fuel cells for lower current applications operating at lower temperatures. If the current is calculated under dynamic condition of an electrolyte, transfer of ions due to the motion of the electrolyte has to be included. At lower current density values activation polarization dominated while at higher current density values, concentration polarization dominated. The voltage loss through the membrane was considered only as ohmic losses. To decrease the ionic losses through the membrane, either the membrane needs to become more conductive or the membrane must be made thinner. It is usually easier to make the membrane thinner because developing a high conductivity electrolyte is very challenging. The material must not only be highly conductive but also stable in a chemical environment and able to withstand the required fuel cell temperatures.

The equation for water content in the membrane presented is applicable only for Nafion. If other type of electrolyte is employed as the membrane, then the equations may need to be altered to suit the chemistry. Fuel cell electrochemical reactions resulted in theoretical cell potential of 1.229 $\mathrm{V}$. Due to the polarization losses the actual potential in operation is lower than $1 \mathrm{~V}$ and required powers of $\mathrm{kW}$ scale. In order to obtain a power of this order, the electrical current generated must be higher than $1000 \mathrm{~A}$. Such a current could be generated only with a large active area $\left(>1000 \mathrm{~cm}^{2}\right)$. Therefore the active area of the fuel cell must be increased which require very thick cables between the fuel cell and a load to minimize the resistive losses. A more practical solution is to have multiple cells, electrically connected in series.

For the simulated fuel cell, operating at $60{ }^{\circ} \mathrm{C}$ temperature, $100 \%$ membrane humidity with an active area of $10 \mathrm{~cm}^{2}$, the maximum power was $8.45 \mathrm{~W}$ at a current density of $1.23 \mathrm{Acm}^{-2}$ representing $82 \%$ of the maximum loading. The corresponding output voltage for the maximum power was $0.693 \mathrm{~V}$ with fuel cell losses around $45 \%$. The variation of maximum power between simulated and the fitted model was $0.208 \mathrm{~W}$. The variation can be reduced by using a higher order function, but the model become complex. When the temperature was increased by one third from its original value $\left(60^{\circ} \mathrm{C}\right.$ to $\left.80{ }^{\circ} \mathrm{C}\right)$, while keeping all other parameters constant maximum power value was increased by $0.571 \mathrm{~W}$.

This is a $6.75 \%$ increase of its original value. In applications with high power fuel cells these percentages may represent power variations in range of several $\mathrm{kW}$. By keeping the temperature constant at $60{ }^{\circ} \mathrm{C}$, when partial pressure of reactants was increased by 10 times, maximum power value was increased by $2.43 \%$. 


\section{References}

[1] M. W. Verbrugge, R.F. Hill, Journal of the Electrochemical Society, 137(12) (1990) 3770-3777

[2] D. M. Bernardi, M. W. Verbrugge, J. A, American Institute of Chemical Engineers (AIChE) 37 (1991) 1151-1163, A, Journal of the Electrochemical Society, 139(9) (1992) 2477-2491.

[3] T.E. Springer, T.A. Zawodzinski, S. Gottesfeld, Journal of the Electrochemical Society, 138(8) (1991) 2334-2342.

[4] V. Gurau, H. Liu, S. Kakac, AIChE Journal 44(11) (1998) 2410-2422. V. Gurau, F.Barbir, H. Liu, J. Electrochem 147 (2000) 2468.

[5] A. Kazim, H. T. Liu, P. Forges, Journal of Applied Electrochemistry 29, (1999) 1409.

[6] D.Singh, D. M. Lu, N. Djilali, International Journal of Engineering Science 37 (1999) 431.

[7] S. Dutta, S.Shimpalee, J. W. Van Zee, Intl. J. of Heat and Mass Transfer, 44/11 (2001) 2029.

[8] L.You, H.Liu, International Journal of Heat and Mass Transfer 45(11) (2002) 2277-2287, Journal of Power Sources 155(2) (2006) 219-230.

[9] K.W.Lum, Three Dimensional Computational Modelling of a Polymer Electrolyte Fuel, $\mathrm{Ph} . D$. dissertation, University of Loughborough (2003).

[10] M. M. Mattew, Fuel Cell Engines. New Jersey: John Wiley \& Sons. (2008)

[11] F.Barbir, PEM Fuel Cells: Theory and Practice, Elsevier Academic Press, San Diego (2005) pp. 147-206.

[12] E. L. Cussler, Diffusion Mass Transfer in Fluid Systems. (Cambridge University. Press, Cambridge, (1997) 101. 